\title{
A Framework for Stormwater Quality Modelling under the Effects of Climate Change to Enhance Reuse
}

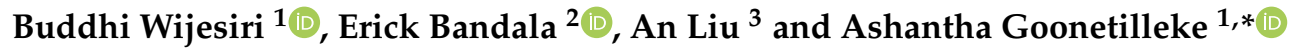 \\ 1 School of Civil and Environmental Engineering, Queensland University of Technology, \\ Brisbane, QLD 4000, Australia; b.mahappukankanamalage@qut.edu.au \\ 2 Division of Hydrologic Sciences, Desert Research Institute, Las Vegas, NV 89119, USA; erick.bandala@dri.edu \\ 3 College of Chemistry and Environmental Engineering, Shenzhen University, Shenzhen 518060, China; \\ liuan@szu.edu.cn \\ * Correspondence: a.goonetilleke@qut.edu.au; Tel.: +61-7-3138-1539
}

Received: 15 October 2020; Accepted: 10 December 2020; Published: 14 December 2020

check for updates

\begin{abstract}
Water scarcity, which is exacerbated by climate change, is a major challenge to ensure human well-being. Therefore, it is equally important to protect conventional water resources from degradation and at the same time to identify cost-effective alternatives with a low carbon footprint. In this regard, stormwater plays a key role as it is a largely under-utilised resource for both, potable and non-potable use. However, stormwater carries substantial loads of pollutants to receiving waters such as rivers. Unfortunately, the lack of comprehensive stormwater quality modelling strategies, which account for the effects of climate change, constrains the formulation of effective measures to improve the quality of stormwater. Currently, there is a significant knowledge gap in the merging of stormwater quality modelling and climate modelling. This paper critically reviews current stormwater quality modelling approaches (quantity and quality) and the role of climate modelling outputs in stormwater quality modelling. This is followed by the presentation of a robust framework to integrate the impacts of climate change with stormwater quality models.
\end{abstract}

Keywords: climate change; stormwater modelling; stormwater quality; stormwater reuse; water scarcity

\section{Introduction}

Urban stormwater is considered a nuisance because it causes flooding and has an impact on aquatic ecosystem health [1-4]. This mindset overlooks the potential to transform stormwater into a safe-to-use resource. While population increase and the impact of climate change exacerbate water scarcity, authorities commonly continue to fail to see urban stormwater as the last available uncommitted water resource for our cities. For example, in 2015, the Australian Senate recommended formulating strategies to optimise stormwater management [5]. Nevertheless, the National Water Account for 2018 (Australia) disregarded treated stormwater as a source of recycled water [6]. The significance of stormwater reuse is related not only to its contribution to meeting the water demand in urban areas, but also to safeguarding conventional water resources $[7,8]$. Given the inevitability of climate change effects on the amount of water resources available to urban settlements, Goonetilleke et al. [9] have urged taking advantage of the opportunities offered by stormwater.

Turning this potentially valuable source of water into a safe-to-use resource requires the removal of pollutants entrained in stormwater. To remove pollutants, understanding the processes that determine their loads/concentrations, including build-up on urban surfaces during dry weather periods and wash-off during wet weather, is a fundamental need. Even though these processes have been investigated under the influence of urbanisation [10-12], pollutant behaviour is subject to variations 
due to the impacts of climate change [13]. Global warming (or more critically, regional warming) results in changes to typical patterns of dry and wet weather periods [14-17], increasing the complexity of changes in stormwater pollutant loads and their characteristics $[17,18]$.

Most studies on the impact of climate change on stormwater only address the changes in runoff quantity in response to changes to rainfall patterns [19-21]. Further, the studies that assess or develop stormwater management measures such as Low-Impact Development (LID) mainly address the control of runoff volume in response to climate change [22-27]. Only a limited number of studies have highlighted the adverse impacts of climate change on stormwater quality [28,29]. However, these studies fail to draw attention to the changes in the patterns of pollutant build-up and wash-off during dry and wet weather periods. The paucity of information and guidance makes it difficult to accurately predict future changes to stormwater quality essential for planning and management decision making in the context of safeguarding stormwater quality and thereby enhancing its reuse.

Predicting stormwater quality is undertaken using mathematical models. The two primary modelling approaches currently used are: (1) physically-based modelling, which replicates temporal and spatial variations in stormwater quality using established physical theory; and (2) statistical modelling for simulating approximations of scenarios subject to a set of observed (field) data. For accurate stormwater quality predictions, the models are required to: (a) encompass robust physical relationships between the changes in stormwater quality and influential factors; and (b) be able to quantify uncertainty in model predictions [30].

Currently, neither (a) nor (b) as articulated above can be measured accurately. Regarding requirement (a) above, the current mathematical formulations of stormwater pollution processes consider dry and wet weather as a static system and do not allow for their dynamic nature resulting from changes driven by global warming [31,32]. Consequently, the accuracy of such mathematical formulations is questionable as weather altered by global warming can change the behaviour of pollutants. For example, large amounts of particulate solids, which carry toxic pollutants, can accumulate on impervious surfaces over longer dry periods, while heavy rainfall can wash-off increasingly large shock-loads of pollutants into receiving waters, exceeding their assimilation capacity. Regarding requirement (b) above, it is inevitable, given the limitations in requirement (a) noted above, that current stormwater quality models do not account for uncertainties that can arise due to the effects of global warming.

In short, stormwater treatment measures lack resilience given that global warming continues to alter dry and wet weather patterns [17]. Hence, the receiving waters remain vulnerable to degradation, and the availability of safe-to-use stormwater will be limited to fulfil the water demands of cities.

This paper critically evaluates the current practices in stormwater quality modelling to identify the changes needed to enhance stormwater quality prediction accuracy. Accordingly, current climate modelling approaches are critically reviewed to identify key aspects of dry and wet weather conditions that need to be accounted for in stormwater quality modelling. This review establishes the platform for climate impact assessment within the context of urban stormwater quality modelling.

\section{Current Practice in Stormwater Quality Modelling and Its Deficiencies}

At a generic level, current stormwater models consist of two modules that operate simultaneously (see Figure 1). The rainfall-runoff module generates information about runoff during a rainfall event. The runoff quality module generates information about pollutant accumulation (build-up) on catchment surfaces during the dry weather period and subsequent wash-off via stormwater runoff [33].

The current stormwater models have been built based on either physically-based (mechanistic) or statistical (or hybrid) modelling approaches. Both approaches have strengths and deficiencies and the resulting models are likely to generate information on stormwater quantity and quality that may not be sufficiently reliable. Hence, there is no stand-alone model that can accurately replicate the entire process of stormwater pollution. For example, commonly used Stormwater Management Model (SWMM) [34,35] and Model for Urban Stormwater Improvement Conceptualisation (MUSIC) [36,37] are appropriate for planning and management decision making, but lack mathematical 
formulations of complex interactions between pollutants that are accounted for in Hydrologic Simulation Program-Fortran (HSPF) [38] model. Further, only a few models such as Mike URBAN [39,40] and HSPF are capable of accounting for the processes of both, dissolved and particulate pollutants. The capabilities and limitations of different modeling tools are detailed in Table 1.

Table 1. Capabilities and limitations of commonly used stormwater quality modelling tools (adapted from Wijesiri [41]).

\begin{tabular}{|c|c|c|c|}
\hline Type & Modelling Tool & Capabilities & Limitations \\
\hline \multirow{6}{*}{ 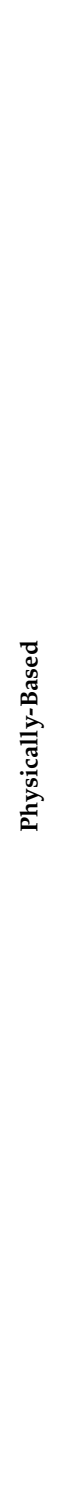 } & $\begin{array}{l}\text { Stormwater Management Model } \\
\text { (SWMM) developed by the US } \\
\text { Environmental Protection } \\
\text { Agency }[34,35]\end{array}$ & $\begin{array}{l}\text { - } \quad \text { Ten different pollutants. } \\
\text { - } \quad \text { Four build-up models: linear, power, exponential } \\
\text { and saturation. } \\
\text { - } \quad \text { Three wash-off models: First order decay, rating } \\
\text { curve and event mean concentration (EMC). } \\
\text { - } \quad \text { Used as a planning and design tool. }\end{array}$ & 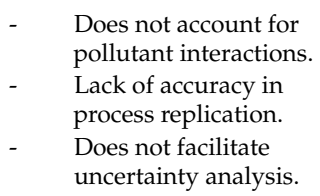 \\
\hline & $\begin{array}{l}\text { Mike URBAN developed by the } \\
\text { Danish Hydraulics } \\
\text { Institute }[39,40]\end{array}$ & $\begin{array}{l}\text { - Number of different pollutants in both, dissolved } \\
\text { and particulate phases. } \\
\text { - } \quad \text { Linear and exponential build-up models. } \\
\text { Wash-off model is based on pollutant detachment } \\
\text { due to the impact of raindrops. } \\
\text { - } \quad \text { Integrated with the capabilities of SWMM. } \\
\text { - } \quad \text { Used as a planning and design tool. }\end{array}$ & $\begin{array}{l}\text { - Greater complexity in } \\
\text { the model structure. } \\
\text { - Lack of accuracy in } \\
\text { process replication. } \\
\text { - } \quad \begin{array}{l}\text { Does not facilitate } \\
\text { uncertainty analysis. }\end{array}\end{array}$ \\
\hline & $\begin{array}{l}\text { Storage, Treatment, Overflow and } \\
\text { Runoff Model (STORM) developed } \\
\text { by the US Corps of Engineers [ } 42 \text { ] }\end{array}$ & $\begin{array}{l}\text { - } \quad \text { Six different pollutants. } \\
\text { Two approaches for build-up modelling: } \\
\text { proportionality between pollutants and } \\
\text { accumulated solids, and linear build-up model as a } \\
\text { function of time. } \\
\text { Wash-off modelling: first order exponential decay } \\
\text { - } \quad \text { proportionality between washed-off and } \\
\text { remaining pollutants). } \\
\text { - Used as a planning tool. }\end{array}$ & $\begin{array}{l}\text { Does not account for } \\
\text { pollutant interactions. } \\
\text { - } \quad \text { Lack of accuracy in } \\
\text { process replications. } \\
\text { - } \quad \begin{array}{l}\text { Does not facilitate } \\
\text { uncertainty analysis. }\end{array}\end{array}$ \\
\hline & $\begin{array}{l}\text { Hydrologic Simulation } \\
\text { Program-Fortran (HSPF) } \\
\text { developed by the US } \\
\text { Environmental Protection } \\
\quad \text { Agency [38] }\end{array}$ & $\begin{array}{l}\text { - } \quad \begin{array}{l}\text { Ten different pollutants in dissolved and } \\
\text { particulate phases. } \\
\text { - }\end{array} \text { Accounts for pollutant interactions. } \\
\text { - } \quad \text { Linear build-up models. } \\
\text { - Wash-off models consider direct proportionality } \\
\text { between wash-off rate of different pollutants } \\
\text { and runoff. } \\
\text { - } \quad \text { Used as a planning and design tool. }\end{array}$ & $\begin{array}{ll}\text { - } & \text { Lack of accuracy in } \\
\text { process replications. } \\
\text { - } & \text { Inefficient calibration. } \\
\text { - } & \text { Does not facilitate } \\
& \text { uncertainty analysis. }\end{array}$ \\
\hline & $\begin{array}{l}\text { Distributed Routing Rainfall } \\
\text { Runoff Model-Quality } \\
\text { (DR3M-QUAL) developed by the } \\
\text { US Geological Survey }[43,44]\end{array}$ & $\begin{array}{ll}\text { - } & \text { Four different pollutants. } \\
\text { - } & \text { Exponential build-up and wash-off models. } \\
\text { - } & \text { Pollutant association with solids. } \\
\text { - } & \text { Used as a planning and design tool. }\end{array}$ & $\begin{array}{l}\text { Does not account for } \\
\text { pollutant interactions. } \\
\text { Lack of accuracy in } \\
\text { process replication. } \\
\text { - } \quad \begin{array}{l}\text { Does not facilitate } \\
\text { uncertainty analysis. }\end{array}\end{array}$ \\
\hline & $\begin{array}{l}\text { Model for Urban Stormwater } \\
\text { Improvement Conceptualisation } \\
\text { (MUSIC) developed by } \\
\text { Cooperative Research Centre for } \\
\text { Catchment Hydrology (CRCCH), } \\
\text { Australia [36,37] }\end{array}$ & $\begin{array}{l}\text { - } \quad \text { Three different pollutants. } \\
\text { Primarily a planning and management decision } \\
\text { support system. } \\
\text { - } \quad \text { Appropriate for conceptual modelling of } \\
\text { stormwater pollution mitigation strategies, and to } \\
\text { evaluate their performance. }\end{array}$ & $\begin{array}{l}\text { - } \quad \text { Not a detailed } \\
\text { modelling tool. } \\
\text { - } \quad \text { Does not account for } \\
\text { pollutant interactions. }\end{array}$ \\
\hline \multirow{2}{*}{ : } & $\begin{array}{l}\text { Derived probability distribution } \\
\text { approach }[45,46]\end{array}$ & \multicolumn{2}{|c|}{$\begin{array}{l}\text { Generates probability distributions of runoff and pollutant loads using the } \\
\text { probability distributions of rainfall characteristics and build-up and } \\
\text { wash-off models. } \\
\text { Facilitates to improve the conceptualization of pollutant processes. } \\
\text { Facilitates to develop stormwater quality control measures. }\end{array}$} \\
\hline & $\begin{array}{l}\text { Bayesian approach with } \\
\text { Metropolis algorithm [47] }\end{array}$ & \multicolumn{2}{|c|}{$\begin{array}{l}\text { Enhances model calibration. } \\
\text { Generates model parameters that optimise the model functions and probability } \\
\text { distributions of those parameters. } \\
\text { Facilitates to improve the conceptualization of pollutant processes. } \\
\text { Lack of sufficient data for model calibration may limit application. }\end{array}$} \\
\hline
\end{tabular}




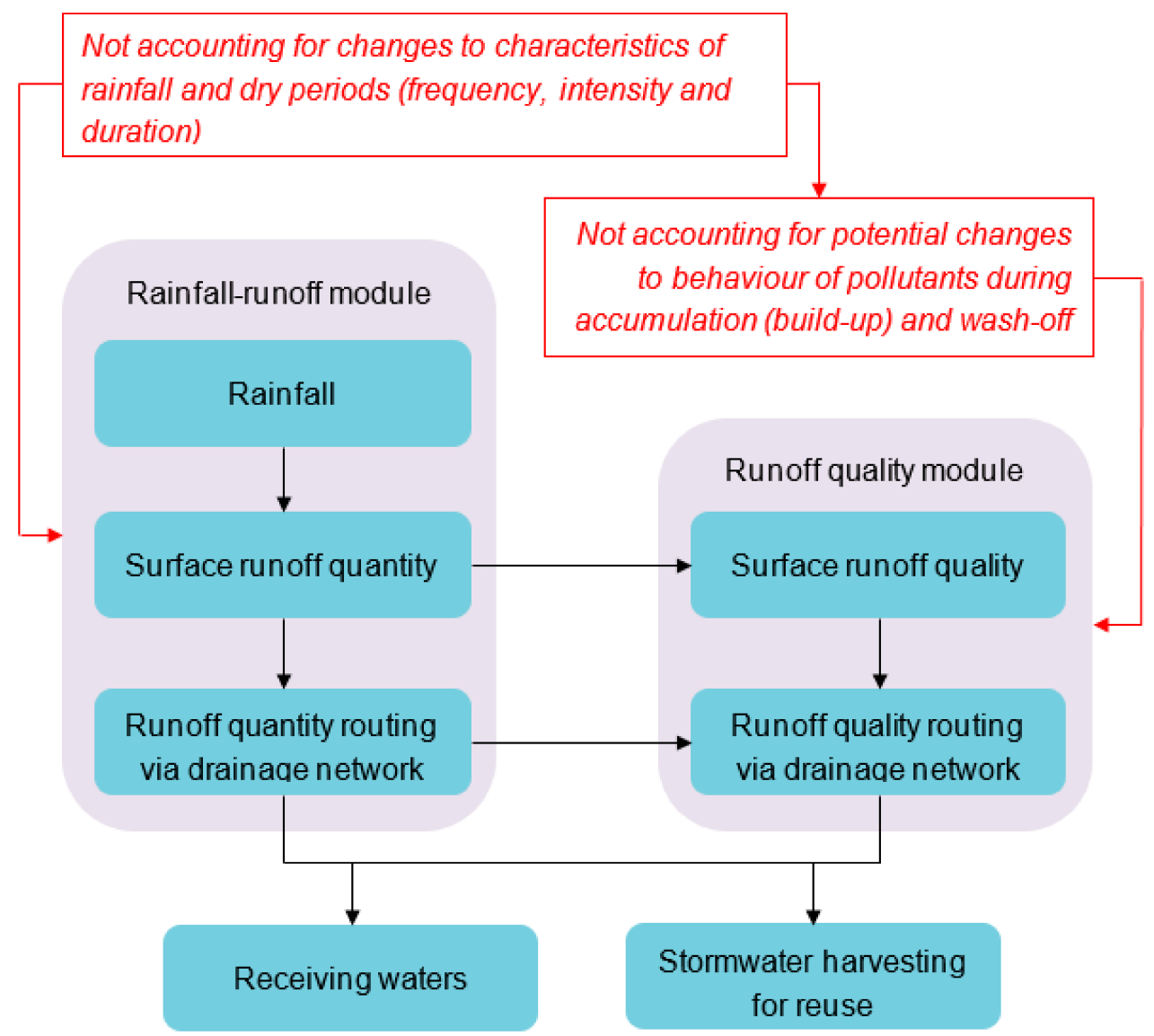

Figure 1. Schematic of the generic structure of current stormwater models (major deficiencies identified are in red text).

In particular, stormwater quality predictions involve various types of uncertainty (due to model structure, data, and parameters) because considerably fewer improvements have been made to the stormwater quality module, compared to the improvements made to the rainfall-runoff (quantity) module. This lack of advancement in stormwater quality modelling is because greater attention has been paid to the mitigation of stormwater quantity-related adverse impacts (e.g., flooding) rather than to improving stormwater quality for reuse [48].

The mathematical formulations included in the runoff quality module are adversely affected by the effects of climate change because the patterns of pollutant build-up and wash-off could change in response to changes in dry and wet weather periods. Therefore, the current mathematical formulations of pollutant build-up and wash-off need enhancements in order to take into consideration the effects of climate change.

Improvements to current mathematical formulations should first consider temporal and spatial patterns of pollutant build-up and wash-off under dry and wet weather conditions influenced by the regional effects of climate change. For example, several regions around the world are projected to experience longer dry periods and more frequent short duration intense rainfall, which have already become evident over the past decade [17]. Under these weather conditions, typical patterns of pollutant build-up (e.g., asymptotic increase towards an equilibrium at around 7-9 antecedent dry days) and wash-off (exponential decay) [49,50] could change as depicted in Figure 2. The pollutant load accumulated is expected to remain at the equilibrium level over a longer period of time (blue line in Figure 2) than typical dry weather events (red line in Figure 2). Consequently, the expected changes to wet weather could result in wash-off of a large amount of accumulated pollutants over a shorter period of time (blue line in Figure 2) than relatively slower wash-off that could occur during typical 
rainfall events (red line in Figure 2). As such, while typical rainfall events would wash-off only a fraction of accumulated pollutants, the rainfall events influenced by climate change could wash-off almost all the accumulated pollutants from catchment surfaces. Further, lesser known effects such as first-flush phenomenon (wash-off of shock loads of pollutants at the initial portion of a rainfall event, see Figure 3) would play a greater role in influencing the quality of stormwater runoff at the catchment outlet.

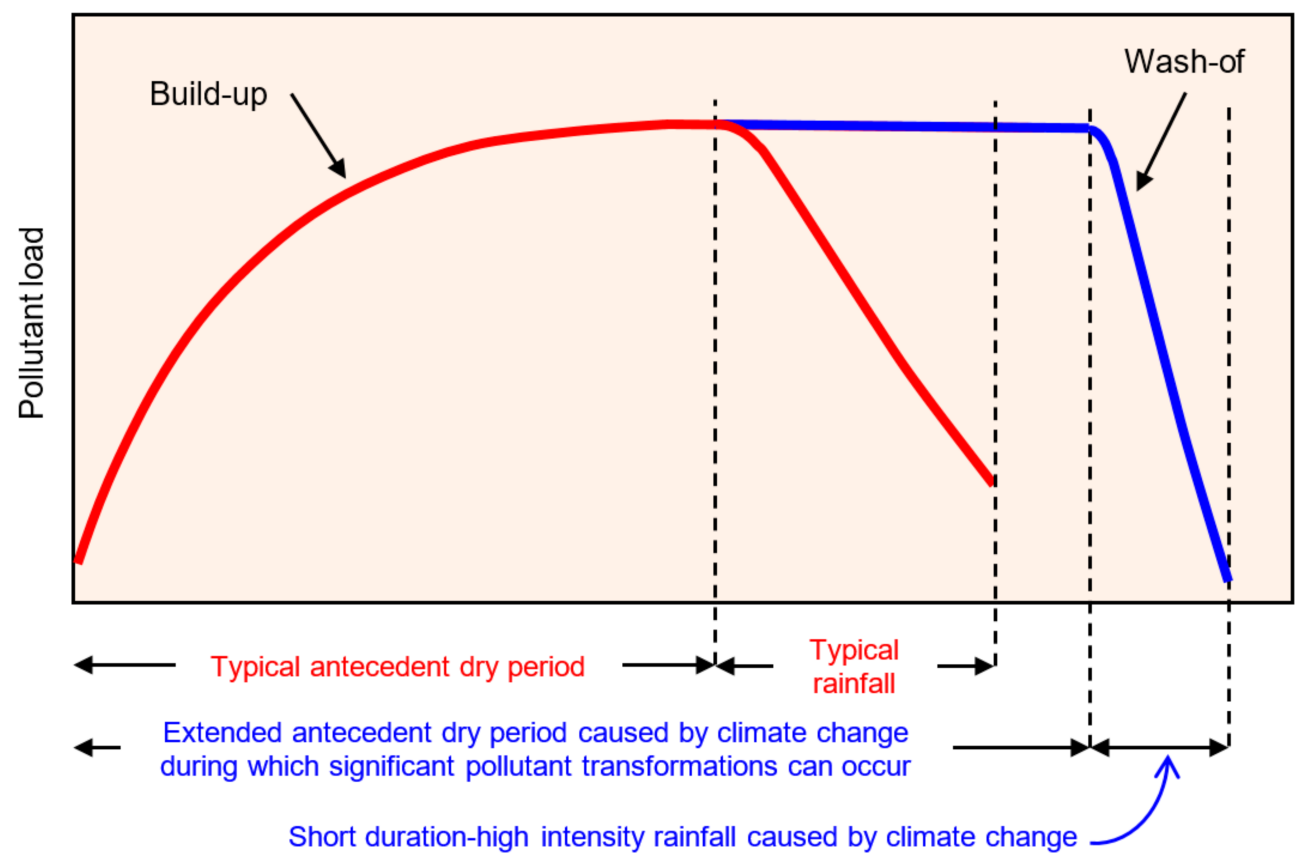

Figure 2. Pollutant behaviour during build-up and wash-off in response to impacts of climate change (X-axis not to scale).

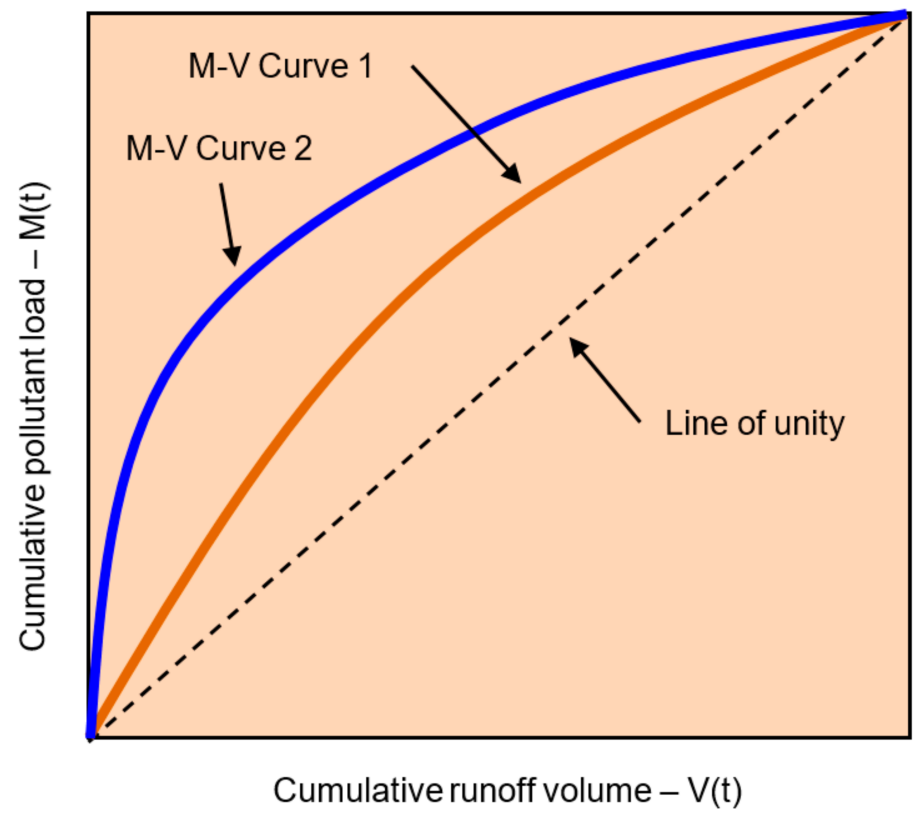

Figure 3. Hypothetical depiction of first-flush. Note: The Mass-Volume (M-V) curves show the relationship between dimensionless $\mathrm{M}$ and $\mathrm{V}$ at a given point in time $(\mathrm{t})$. As such, first flush occurs when the $\mathrm{M}-\mathrm{V}$ curve lies above the line of unity. $\mathrm{M}-\mathrm{V}$ curve 1 shows first-flush during a typical rainfall event, while $\mathrm{M}-\mathrm{V}$ curve 2 shows first flush during a rainfall event affected by climate change (adapted from Perera et al. [51]). 


\section{Role of Climate Modelling Outputs in Stormwater Quality Modelling}

Climate modelling entails the mathematical formulation and integration of energy and matter transfer on the land, atmosphere and ocean. The outcomes of climate models (general circulation models (GCMs)) indicate the probability of a given area having relatively warmer/cooler or wetter/drier climate, which is different from typical weather reports of daily wet/dry conditions.

With the objective of broadening the understanding of climate change in the historical, current, and future contexts, the Coupled Model Intercomparison Project (CMIP) brings together multiple climate modelling groups from across the world. The CMIP makes standardised output of climate models available to other researchers who are involved in climate change impact assessments. Detailed information about CMIP phases can be accessed via World Climate Research Program (WCRP) and the Program for Climate Model Diagnosis and Intercomparison (PCMDI) of the US Department of Energy. Meanwhile, the most recent phase, CMIP6, provides information that may be useful for the mathematical formulation of stormwater pollution processes under the effects of climate change.

CMIP6 addresses three issues broadly related to the Earth's climate system under 12 scientific themes (clouds/circulation, regional phenomena, ocean/land/ice, impacts, scenarios, decadal prediction, geo-engineering, land use, carbon cycle, chemistry/aerosols, characterising forcing, and paleo) [52]:

Issue 1: Response of Earth's climate system to radiative forcing: The radiative forcing (difference between energy absorbed by and radiated back from the Earth) changes due to natural/anthropogenic emissions. Consequently, land, ocean and atmospheric temperatures could change, and in turn, variables such as precipitation could also change.

Stormwater quality perspective: Changes to dry and wet weather patterns are the two key responses that need to be incorporated into the mathematical formulations of stormwater pollution processes such as build-up and wash-off. Fundamental changes to the structure of current mathematical functions are necessary due to changes to pollution processes (such as lengthy equilibrium periods during build-up and intense first flush events that lasts for shorter periods during wash-off, see Figures 2 and 3 ).

Issue 2: Systematic model biases: Climate models are expected to replicate complex climate processes, which can exhibit substantial inherent variability, particularly at the regional scale. As such, model biases are likely to arise, leading to over/under estimations of future climate.

Stormwater quality perspective: Current stormwater models already have deficiencies relating to model structure, input and calibration data, and model parameters specific to underlying processes such as coefficients of pollutant build-up and wash-off [53,54]. Understanding systematic biases in climate models and minimising their effects are necessary when using climate projections for stormwater quality modelling.

Issue 3: Assessment of future changes in climate under climate variability, predictability and uncertainty in future scenarios: The future climate scenarios are developed based on the expected changes to socio-economic systems that contribute to emissions. These scenarios are associated with uncertainty, which are accounted for when undertaking climate impact assessments.

Stormwater quality perspective: Stormwater pollution processes can be influenced by the variability in climate processes (precipitation and dry period), which leads to creating uncertainty in stormwater quality projections. Therefore, it is also necessary to address the effects of such uncertainty when projecting stormwater quality into the future.

Accordingly, five themes can be proposed (out of the 12 listed above) that have potential implications for stormwater quality modelling. These include cloud/circulation, regional phenomena, land use, scenarios and impacts. The outputs of the model intercomparison projects (MIPs) under clouds/circulation theme $[55,56]$ are a guide to identifying the appropriate climate models that produce precipitation/dry period projections, which can contribute to stormwater quality modelling (see Figure 4). 


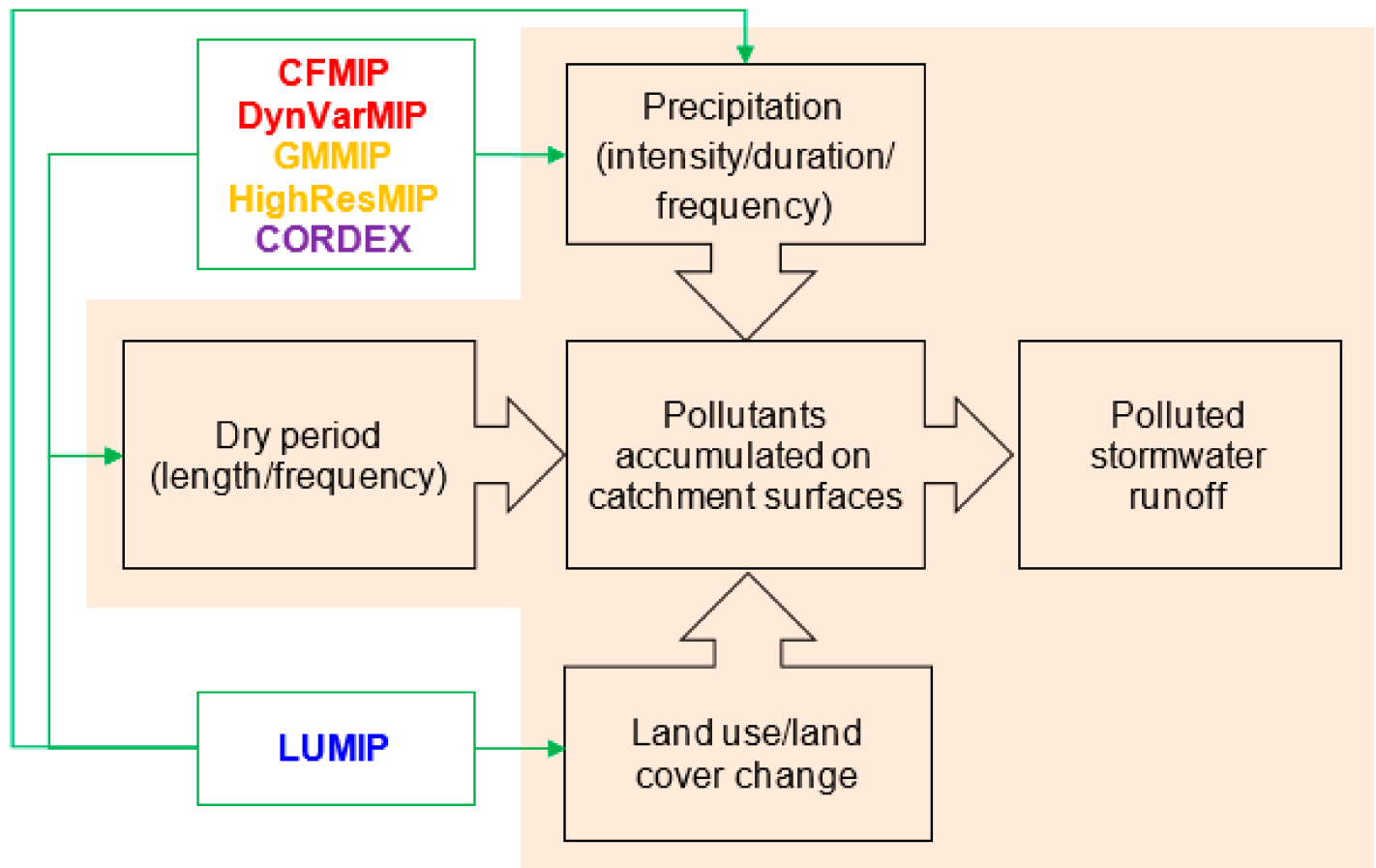

Model Intercomparison Projects (MIPs) under each theme

Clouds/circulation theme: CFMIP and DynVarMIP

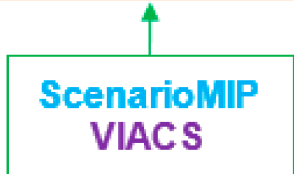

Regional Phenomena theme: GMMIP and HighResMIP

Land Use theme: LUMIP

Scenarios theme: ScenarioMIP

Impacts theme: VIACS and CORDEX

Figure 4. Framework for incorporating various climate modelling outputs of Model Intercomparison Projects (MIPs) under the proposed five themes into specific elements of stormwater quality modelling. Note: CFMIP-Cloud Feedback Model Intercomparison Project [55]; DynVarMIP-Dynamics and Variability Model Intercomparison Project [56]; GMMIP—Global Monsoons Model Inter-comparison Project [57]; HighResMIP—High Resolution Model Intercomparison Project [58]; LUMIP—Land Use Model Intercomparison Project [59]; ScenarioMIP—Scenario Model Intercomparison Project [60]; VIACS-Vulnerability, Impacts, Adaptation and Climate Services [61]; CORDEX-Coordinated Regional Downscaling Experiment [62].

The outputs of the MIPs under Regional Phenomena theme [57,58] provide key information on the variability in monsoon system, which could substantially alter the length of dry periods (mega droughts) and result in heavy storms and large flood events. These significantly exacerbate the quality of stormwater, while flooding contributes to disperse pollutants across multiple areas.

In a recent study conducted in the North Australia region [13], the likely impacts of the climate change-driven variations in dry and wet weather events have been demonstrated. Due to an increase in atmospheric temperature by $1.5^{\circ} \mathrm{C}$ (around year 2030-2052) above pre-industrial levels, North Australia region is projected to experience (compared to year 2007) dry periods that are extended by 4.72 days (range of variation at RCP 8.5 warming scenario: 3.67-11.93 days) and increase in rainfall by $0.31 \mathrm{~mm}$ (range of variation at RCP 8.5 warming scenario: $0-4.50 \mathrm{~mm}$ ). These projections are set to worsen due to an additional $0.5^{\circ} \mathrm{C}$ increase in temperature (i.e., $2{ }^{\circ} \mathrm{C}$ above pre-industrial levels), such that dry periods in North Australia can be 7.34 days longer (range of variation at RCP 8.5 warming scenario: 5.11-17.96 days) and the region can expect to receive $1.40 \mathrm{~mm}$ more rainfall (range of variation at RCP 8.5 warming scenario: $0-5.58 \mathrm{~mm}$ ). As a result of these projected changes in dry and wet 
weather, Wijesiri et al. [13] estimated (compared to year 2007) a more than $90 \%$ increase in the build-up of particle-bound toxicants such as heavy metals and nearly a 50\% increase in those pollutants in stormwater runoff.

Given that extreme weather events mostly occur at smaller spatial scales, reliable climate projections under this Regional Phenomena theme could be crucial for stormwater quality modelling (see Figure 4), as stormwater quality exhibits substantial variability at catchment scale as well as between geographic regions [12].

Furthermore, land use is a key determinant of the quantity and type of pollutants released into stormwater runoff, although the effects of land use change have not been adequately accounted for in current stormwater models [63]. On the other hand, anthropogenic activities specific to different types of land use contribute to the emission of aerosols and greenhouse gases. This has implications to the climate such as extreme droughts and heavy precipitation [64]. The outputs of the MIPs under Land Use theme [59] play a key role in influencing the relationships between spatial and temporal changes in land use/land cover that contribute to both, climate change (and its effects on dry and wet weather) and pollutant accumulation on catchment surfaces (see Figure 4).

Various scenarios of how physical and human systems are expected to change in the future and their impacts on the climate system are important for projecting future climate change. The MIPs outputs under scenarios theme [60] provides climate projections of future scenarios of emissions and land use change. These scenarios are developed based on future pathways of inherently uncertain socio-economic developments, which also contribute to stormwater pollution, including pollutant generation, deposition and subsequent re-distribution during dry weather periods and wash-off during rainfall events. Therefore, the future climate scenarios could be the basis for projecting stormwater quality into the future (see Figure 4) and in turn for designing robust measures to enhance stormwater reuse.

Regarding climate impact assessment, usually a two-way dialogue is established between the climate modelling community and those who expect to utilise model outcomes for assessing the impacts on various human-environmental systems [61]. Further, one of the crucial elements of impact assessment is downscaling of regional climate projections. This plays a key role in stormwater quality modelling due to the regional variability in the factors that influence pollutant generation and subsequent distribution during dry and wet weather events. Accordingly, the outputs of MIPs under the impacts theme [62] provide a common framework to produce downscaled regional climate projections and to assess associated uncertainties, which can be considered for stormwater quality modelling to ensure the robustness in the projection of regional scale stormwater quality (see Figure 4).

\section{Future Research Directions}

Despite the call for actions towards the mitigation of the impacts of climate change [65], urban areas are still far from ensuring human well-being and the safety of ecosystems. In relation to stormwater, there are two major areas of research being undertaken, namely, flood mitigation and stormwater treatment. Efforts to predict flood events and identifying flood-prone areas have at least started to address the effects of changing weather patterns [66-68]. However, research on stormwater treatment is still largely focused on resizing existing treatment measures such as Water Sensitive Urban Design (WSUD) systems. For example, Zhang et al. [69] report that the treatment performance of WSUD systems would not significantly change in future climate change scenarios, and recommend slightly larger systems for reliable performance. However, they have only accounted for the impact of simulated future weather patterns on the volume of stormwater runoff. There is a knowledge gap in the accounting of how these simulated rainfall and dry periods influence pollutant behaviour on urban impervious surfaces, and in particular, phenomena such as first flush. As such, the current state of research on stormwater treatment does not affirm the resilience of these systems, without which they would be ineffective in the long-term in response to climate change. Therefore, a significant step change 
is necessary in terms of merging stormwater and climate research outcomes, rather the application of resources for simply improving available technologies.

\section{Conclusions}

This review has identified deficiencies in existing stormwater quality models in relation to addressing the effects of climate change. As such, it is recommended that: (1) the rainfall-runoff (quantity) module should be incorporated with mathematical formulations of the changes to the characteristics of rainfall and dry periods (frequency, intensity and duration) caused by global/regional warming; and (2) the runoff quality module should be incorporated with mathematical formulations of the potential changes to the patterns of pollutant accumulation (build-up) and wash-off. Additionally, the runoff quality module needs significant improvements due to the complex behaviour of pollutants in response to climate-change-influenced changes to dry and wet weather events. Therefore, five themes within the latest phase of CMIP (CMIP6) are proposed as a basis to account for the effects of climate change on stormwater quality. Collectively, the five themes (cloud/circulation, regional phenomena, land use, scenarios and impact assessment) are expected to provide guidance for accounting for the changes to dry and wet weather patterns by radiative forcing under various future socio-economic developments (future climate scenarios), effects of systematic climate model biases on climate projections, natural variability in climate processes, and uncertainties in climate projections, in the formulation of technically robust stormwater quality models.

Author Contributions: Conceptualization, B.W., E.B., A.L. and A.G.; writing-original draft preparation, B.W.; writing-review and editing, E.B., A.L. and A.G. All authors have read and agreed to the published version of the manuscript.

Funding: This research was funded by Guangdong Basic and Applied Basic Research Foundation, China, grant number 2019A1515110353 and 2019A1515010843, and Key-Area Research and Development Program of Guangdong Province, grant number 2019B110205003.

Conflicts of Interest: The authors declare no conflict of interest. The funders had no role in the design of the study; in the collection, analyses, or interpretation of data; in the writing of the manuscript; or in the decision to publish the results.

\section{References}

1. Mignot, E.; Li, X.; Dewals, B. Experimental modelling of urban flooding: A review. J. Hydrol. 2019, 568, 334-342. [CrossRef]

2. Petit-Boix, A.; Sevigné-Itoiz, E.; Rojas-Gutierrez, L.A.; Barbassa, A.P.; Josa, A.; Rieradevall, J.; Gabarrell, X. Floods and consequential life cycle assessment: Integrating flood damage into the environmental assessment of stormwater Best Management Practices. J. Clean. Prod. 2017, 162, 601-608. [CrossRef]

3. Burns, M.J.; Schubert, J.E.; Fletcher, T.D.; Sanders, B.F. Testing the impact of at-source stormwater management on urban flooding through a coupling of network and overland flow models. Wires Water 2015, 2, $291-300$. [CrossRef]

4. Beaudry, M. From Nuisance to Resource: Understanding Microbial Sources of Contamination in Urban Stormwater-Impacted Bodies of Water Intended for Water Reuse Activities; University of Alberta: Edmonton, AB, Canada, 2019.

5. ECRC. Stormwater Management in Australia; Commonwealth of Australia: Canberra, Australia, 2015.

6. BoM. Water in Australia 2017-2018; Commonwealth of Australia, Bureau of Meteorology: Melbourne, Australia, 2019.

7. Walsh, C.J.; Fletcher, T.D.; Bos, D.G.; Imberger, S.J. Restoring a stream through retention of urban stormwater runoff: A catchment-scale experiment in a social-ecological system. Freshw. Sci. 2015, 34, 1161-1168. [CrossRef]

8. Goonetilleke, A.; Liu, A.; Gardner, T. Briefs for GSDR-Urban Stormwater Reuse: An Agenda for Sustainable Development; UN Global Sustainable Development Report; UN Department of Economic and Social Affairs: New York, NY, USA, 2016.

9. Goonetilleke, A.; Liu, A.; Managi, S.; Wilson, C.; Gardner, T.; Bandala, E.R.; Walker, L.; Holden, J.; Wibowo, M.A.; Suripin, S. Stormwater reuse, a viable option: Fact or fiction? Econ. Anal. Policy 2017, 56, 14-17. [CrossRef] 
10. Hamel, P.; Daly, E.; Fletcher, T.D. Source-control stormwater management for mitigating the impacts of urbanisation on baseflow: A review. J. Hydrol. 2013, 485, 201-211. [CrossRef]

11. Wei, T.; Wijesiri, B.; Jia, Z.; Li, Y.; Goonetilleke, A. Re-thinking classical mechanistic model for pollutant build-up on urban impervious surfaces. Sci. Total Environ. 2019, 651, 114-121. [CrossRef]

12. Wijesiri, B.; Liu, A.; Gunawardana, C.; Hong, N.; Zhu, P.; Guan, Y.; Goonetilleke, A. Influence of urbanisation characteristics on the variability of particle-bound heavy metals build-up: A comparative study between China and Australia. Environ. Pollut. 2018, 242, 1067-1077. [CrossRef]

13. Wijesiri, B.; Liu, A.; Goonetilleke, A. Impact of global warming on urban stormwater quality: From the perspective of an alternative water resource. J. Clean. Prod. 2020, 121330. [CrossRef]

14. King, A.D.; Karoly, D.J.; Henley, B.J. Australian climate extremes at $1.5 \mathrm{C}$ and 2 C of global warming. Nat. Clim. Chang. 2017, 7, 412. [CrossRef]

15. Chevuturi, A.; Klingaman, N.P.; Turner, A.G.; Hannah, S. Projected Changes in the Asian-Australian Monsoon Region in $1.5^{\circ} \mathrm{C}$ and $2.0^{\circ} \mathrm{C}$ Global-Warming Scenarios. Earth's Future 2018, 6, 339-358. [CrossRef]

16. IPCC. Managing the Risks of Extreme Events and Disasters to Advance Climate Change Adaptation. A Special Report of Working Groups I and II of the Intergovernmental Panel on Climate Change; Field, C.B., Barros, V., Stocker, T.F., Qin, D., Dokken, D.J., Ebi, K.L., Mastrandrea, M.D., Mach, K.J., Plattner, G.-K., Allen, S.K., et al., Eds.; Cambridge University Press: Cambridge, UK; New York, NY, USA, 2012.

17. IPCC. Global Warming of $1.5^{\circ} \mathrm{C}$. An IPCC Special Report on the Impacts of Global Warming of $1.5{ }^{\circ} \mathrm{C}$ above Pre-Industrial Levels and Related Global Greenhouse Gas Emission Pathways, in the Context of Strengthening the Global Response to the Threat of Climate Change, Sustainable Development, and Efforts to Eradicate Poverty; Masson-Delmotte, V., Zhai, P., Pörtner, H.O., Roberts, D., Skea, J., Shukla, P.R., Pirani, A., Moufouma-Okia, W., Péan, C., Pidcock, R., et al., Eds.; World Meteorological Organization: Geneva, Switzerland, 2018.

18. IPCC. Climate Change 2014: Mitigation of Climate Change. Contribution of Working Group III to the Fifth Assessment Report of the Intergovernmental Panel on Climate Change; Edenhofer, O., Pichs-Madruga, R.Y., Sokona, E.F., Kadner, S., Seyboth, K., Adler, A., Baum, I., Brunner, S., Eickemeier, P., Kriemann, B., et al., Eds.; Cambridge University Press: Cambridge, UK; New York, NY, USA, 2014.

19. Donnelly, C.; Greuell, W.; Andersson, J.; Gerten, D.; Pisacane, G.; Roudier, P.; Ludwig, F.J.C.C. Impacts of climate change on European hydrology at 1.5, 2 and 3 degrees mean global warming above preindustrial level. Clim. Chang. 2017, 143, 13-26. [CrossRef]

20. Zhai, R.; Tao, F.; Xu, Z. Spatial-temporal changes in runoff and terrestrial ecosystem water retention under 1.5 and $2{ }^{\circ} \mathrm{C}$ warming scenarios across China. Earth Syst. Dyn. 2018, 9, 717-738. [CrossRef]

21. Semadeni-Davies, A.; Hernebring, C.; Svensson, G.; Gustafsson, L.-G. The impacts of climate change and urbanisation on drainage in Helsingborg, Sweden: Suburban stormwater. J. Hydrol. 2008, 350, 114-125. [CrossRef]

22. Cook, L.M.; McGinnis, S.; Samaras, C. The effect of modeling choices on updating intensity-duration-frequency curves and stormwater infrastructure designs for climate change. Clim. Chang. 2020, 159, 289-308. [CrossRef]

23. Brudler, S.; Arnbjerg-Nielsen, K.; Hauschild, M.Z.; Rygaard, M. Life cycle assessment of stormwater management in the context of climate change adaptation. Water Res. 2016, 106, 394-404. [CrossRef]

24. Thakali, R.; Kalra, A.; Ahmad, S. Understanding the effects of climate change on urban stormwater infrastructures in the Las Vegas Valley. Hydrology 2016, 3, 34. [CrossRef]

25. Zahmatkesh, Z.; Burian, S.J.; Karamouz, M.; Tavakol-Davani, H.; Goharian, E. Low-Impact Development Practices to Mitigate Climate Change Effects on Urban Stormwater Runoff: Case Study of New York City. J. Irrig. Drain. Eng. 2015, 141, 04014043. [CrossRef]

26. Pyke, C.; Warren, M.P.; Johnson, T.; LaGro, J.; Scharfenberg, J.; Groth, P.; Freed, R.; Schroeer, W.; Main, E. Assessment of low impact development for managing stormwater with changing precipitation due to climate change. Landsc. Urban Plan. 2011, 103, 166-173. [CrossRef]

27. Giese, E.; Rockler, A.; Shirmohammadi, A.; Pavao-Zuckerman, M.A. Assessing Watershed-Scale Stormwater Green Infrastructure Response to Climate Change in Clarksburg, Maryland. J. Water Resour. Plan. Manag. 2019, 145, 05019015. [CrossRef]

28. Saraswat, C.; Kumar, P.; Mishra, B.K. Assessment of stormwater runoff management practices and governance under climate change and urbanization: An analysis of Bangkok, Hanoi and Tokyo. Environ. Sci. Policy 2016, 64, 101-117. [CrossRef] 
29. Wang, M.; Zhang, D.; Adhityan, A.; Ng, W.J.; Dong, J.; Tan, S.K. Assessing cost-effectiveness of bioretention on stormwater in response to climate change and urbanization for future scenarios. J. Hydrol. 2016, 543, 423-432. [CrossRef]

30. Bell, C.D.; McMillan, S.K.; Clinton, S.M.; Jefferson, A.J. Hydrologic response to stormwater control measures in urban watersheds. J. Hydrol. 2016, 541 Pt B, 1488-1500. [CrossRef]

31. Wijesiri, B.; Egodawatta, P.; McGree, J.; Goonetilleke, A. Assessing Uncertainty in Pollutant Build-up and Wash-off Processes. Environ. Pollut. 2016, 212, 48-56. [CrossRef] [PubMed]

32. WWAP. The United Nations World Water Development Report 4: Managing Water under Uncertainty and Risk (Volume 1); UNESCO: Paris, France, 2012.

33. Liu, A.; Goonetilleke, A.; Egodawatta, P. Role of Rainfall and Catchment Characteristics on Urban Stormwater Quality; Springer: Singapore, 2015.

34. Rossman, L.A. Storm Water Management Model User's Manual Version 5.1; US EPA Office of Research and Development: Washington, DC, USA, 2015.

35. Huber, W.C.; Dickinson, R.E. Storm Water Management Model, Version 4: User's Manual; US Enviornmental Protection Agency: Athens, GA, USA, 1988.

36. Wong, T.H.; Fletcher, T.D.; Duncan, H.P.; Coleman, J.R.; Jenkins, G.A. A model for urban stormwater improvement: Conceptualization. In Global Solutions for Urban Drainage; Srecker, E.W., Huber, W.C., Eds.; American Society of Civil Engineers: Reston, VA, USA, 2002; pp. 1-14.

37. Wong, T.H.F.; Fletcher, T.D.; Duncan, H.P.; Jenkins, G.A. Modelling Urban Stormwater Treatment-A Unified Approach. Ecol. Eng. 2006, 27, 58-70. [CrossRef]

38. Bicknell, B.R.; Imhoff, J.C.; Kittle, J.L., Jr.; Donigian, A.S., Jr.; Johanson, R.C. Hydrological Simulation Program-Fortran: User's Manual Version 11; U.S. Environmental Protection Agency, National Exposure Research Laboratory: Athens, GA, USA, 1997.

39. MikeUrban. Mouse Pollution Transport: Reference Manual—Surface Runoff Quality; Danish Hydraulic Institue: Hørsholm, Denmark, 2017.

40. MikeUrban. Mike Urban Collection System - User Guide; Danish Hydraulic Institute: Hørsholm, Denmark, 2014.

41. Wijesiri, B. Assessing Uncertainty in Relation to Urban Stormwater Pollutant Processes; Queensland University of Technology (QUT): Brisbane, Australia, 2016.

42. HEC. Storage, Treatment, Overflow, Runoff Model, STORM, Generalized Computer Program 723-58-L7520; Hydrologic Engineering Center, U.S. Corps of Engineers: Davis, CA, USA, 1977.

43. Alley, W.M.; Smith, P.E. Multi-Event Urban Runoff Quality Model; U.S. Geological Survey: Reston, VA, USA, 1982.

44. Alley, W.M.; Smith, P.E. Distributed Routing Rainfall-Runoff Model: Version 2; U.S. Geological Survey: Denver, CO, USA, 1982.

45. Chen, J.; Adams, B.J. A Derived Probability Distribution Approach to Stormwater Quality Modeling. Adv. Water Resour. 2007, 30, 80-100. [CrossRef]

46. Chen, J.; Adams, B.J. A Framework for Urban Storm Water Modeling and Control Analysis with Analytical Models. Water Resour. Res. 2006, 42, 1-13. [CrossRef]

47. Kanso, A.; Gromaire, M.-C.; Gaume, E.; Tassin, B.; Chebbo, G. Bayesian Approach for the Calibration of Models: Application to an Urban Stormwater Pollution Model. Water Sci. Technol. 2003, 47, 77-84. [CrossRef]

48. Wijesiri, B.; Egodawatta, P.; McGree, J.; Goonetilleke, A. Understanding the Uncertainty Associated with Particle-bound Pollutant Build-up and Wash-off: A Critical Review. Water Res. 2016, 101, 582-596. [CrossRef]

49. Egodawatta, P.; Thomas, E.; Goonetilleke, A. Mathematical Interpretation of Pollutant Wash-off from Urban Road Surfaces Using Simulated Rainfall. Water Res. 2007, 41, 3025-3031. [CrossRef]

50. Wijesiri, B.; Egodawatta, P.; McGree, J.; Goonetilleke, A. Influence of Pollutant Build-up on Variability in Wash-off from Urban Road Surfaces. Sci. Total Environ. 2015, 527-528, 344-350. [CrossRef] [PubMed]

51. Perera, T.; McGree, J.; Egodawatta, P.; Jinadasa, K.B.S.N.; Goonetilleke, A. Taxonomy of influential factors for predicting pollutant first flush in urban stormwater runoff. Water Res. 2019, 166, 115075. [CrossRef] [PubMed]

52. Eyring, V.; Bony, S.; Meehl, G.A.; Senior, C.A.; Stevens, B.; Stouffer, R.J.; Taylor, K.E. Overview of the Coupled Model Intercomparison Project Phase 6 (CMIP6) experimental design and organization. Geosci. Model Dev. 2016, 9, 1937-1958. [CrossRef] 
53. Bonhomme, C.; Petrucci, G. Should we trust build-up/wash-off water quality models at the scale of urban catchments? Water Res. 2017, 108, 422-431. [CrossRef] [PubMed]

54. Hong, Y.; Bonhomme, C.; Le, M.-H.; Chebbo, G. A new approach of monitoring and physically-based modelling to investigate urban wash-off process on a road catchment near Paris. Water Res. 2016, 102, 96-108. [CrossRef]

55. Webb, M.J.; Andrews, T.; Bodas-Salcedo, A.; Bony, S.; Bretherton, C.S.; Chadwick, R.; Chepfer, H.; Douville, H.; Good, P.; Kay, J.E.J.G.M.D. The cloud feedback model intercomparison project (CFMIP) contribution to CMIP6. Geosci. Model Dev. 2017, 2017, 359-384. [CrossRef]

56. Gerber, E.P.; Manzini, E.J.G.M.D. The Dynamics and Variability Model Intercomparison Project (DynVarMIP) for CMIP6: Assessing the stratosphere-troposphere system. Geosci. Model Dev. 2016, 9, 3413-3425. [CrossRef]

57. Zhou, T.; Turner, A.G.; Kinter, J.L.; Wang, B.; Qian, Y.; Chen, X.; Wu, B.; Liu, B.; Zou, L.; Bian, H.J.G.M.D. GMMIP (v1. 0) contribution to CMIP6: Global monsoons model inter-comparison project. Geosci. Model Dev. 2016, 9, 3589-3604. [CrossRef]

58. Haarsma, R.J.; Roberts, M.J.; Vidale, P.L.; Senior, C.A.; Bellucci, A.; Bao, Q.; Chang, P.; Corti, S.; Fučkar, N.S.; Guemas, V.J.G.M.D. High resolution model intercomparison project (HighResMIP v1. 0) for CMIP6. Geosci. Model Dev. 2016, 9, 4185-4208. [CrossRef]

59. Lawrence, D.M.; Hurtt, G.C.; Arneth, A.; Brovkin, V.; Calvin, K.V.; Jones, A.D.; Jones, C.D.; Lawrence, P.J.; de Noblet-Ducoudré, N.; Pongratz, J.J.G.M.D. The Land Use Model Intercomparison Project (LUMIP) contribution to CMIP6: Rationale and experimental design. Geosci. Model Dev. 2016, 9, 2973-2998. [CrossRef]

60. O’Neill, B.C.; Tebaldi, C.; van Vuuren, D.P.; Eyring, V.; Friedlingstein, P.; Hurtt, G.; Knutti, R.; Kriegler, E.; Lamarque, J.F.; Lowe, J.; et al. The Scenario Model Intercomparison Project (ScenarioMIP) for CMIP6. Geosci. Model Dev. 2016, 9, 3461-3482. [CrossRef]

61. Ruane, A.C.; Teichmann, C.; Arnell, N.W.; Carter, T.R.; Ebi, K.L.; Frieler, K.; Goodess, C.M.; Hewitson, B.; Horton, R.; Kovats, R.S. The vulnerability, impacts, adaptation and climate services advisory board (VIACS AB v1. 0) contribution to CMIP6. Geosci. Model Dev. 2016, 9, 3493-3515. [CrossRef]

62. Gutowski, W.J., Jr.; Giorgi, F.; Timbal, B.; Frigon, A.; Jacob, D.; Kang, H.S.; Raghavan, K.; Lee, B.; Lennard, C.; Nikulin, G.; et al. WCRP COordinated Regional Downscaling EXperiment (CORDEX): A diagnostic MIP for CMIP6. Geosci. Model Dev. 2016, 9, 4087-4095. [CrossRef]

63. Gunawardena, J.M.; Liu, A.; Egodawatta, P.; Ayoko, G.A.; Goonetilleke, A. Influence of Traffic and Land Use on Urban Stormwater Quality: Implications for Urban Stormwater Treatment Design; Springer: Singapore, 2017.

64. Greve, P.; Orlowsky, B.; Mueller, B.; Sheffield, J.; Reichstein, M.; Seneviratne, S.I.J.N.g. Global assessment of trends in wetting and drying over land. Nat. Geosci. 2014, 7, 716-721. [CrossRef]

65. WEF. The Global Risks Report 2019, 14th ed.; World Economic Forum: Geneva, Switzerland, 2019.

66. Pasquier, U.; Few, R.; Goulden, M.C.; Hooton, S.; He, Y.; Hiscock, K.M. “We can't do it on our own!"-Integrating stakeholder and scientific knowledge of future flood risk to inform climate change adaptation planning in a coastal region. Environ. Sci. Policy 2020, 103, 50-57. [CrossRef]

67. Cloke, H.L.; Wetterhall, F.; He, Y.; Freer, J.E.; Pappenberger, F. Modelling climate impact on floods with ensemble climate projections. Q. J. R. Meteorol. Soc. 2013, 139, 282-297. [CrossRef]

68. Västilä, K.; Kummu, M.; Sangmanee, C.; Chinvanno, S. Modelling climate change impacts on the flood pulse in the Lower Mekong floodplains. J. Water Clim. Chang. 2010, 1, 67-86. [CrossRef]

69. Zhang, K.; Manuelpillai, D.; Raut, B.; Deletic, A.; Bach, P.M. Evaluating the reliability of stormwater treatment systems under various future climate conditions. J. Hydrol. 2019, 568, 57-66. [CrossRef]

Publisher's Note: MDPI stays neutral with regard to jurisdictional claims in published maps and institutional affiliations.

(C) 2020 by the authors. Licensee MDPI, Basel, Switzerland. This article is an open access article distributed under the terms and conditions of the Creative Commons Attribution (CC BY) license (http://creativecommons.org/licenses/by/4.0/). 